\title{
Personal-Care Cosmetic Practices in Pakistan: Current Perspectives and Management
}

This article was published in the following Dove Press journal:

Clinical, Cosmetic and Investigational Dermatology

\author{
Nazeer Hussain Khan (D) ${ }^{1,2}$ \\ Faiz Ullah ${ }^{3}$ \\ Taskin Aman Khan ${ }^{4}$ \\ Ujala Zafar ${ }^{5}$ \\ Muhammad Farhan Ali Khan ${ }^{6}$ \\ Muhammad Mustaqeem ${ }^{7}$ \\ Syed Sakhawat Shah ${ }^{3}$ \\ Dong-Dong $\mathrm{Wu}\left(\mathbb{D}^{1,8}\right.$ \\ Xin-Ying Ji $\mathbb{D}^{\prime}$
}

'Henan International Joint Laboratory for Nuclear Protein Regulation, Henan University, Henan 47500I, People's Republic of China; ${ }^{2}$ School of Life Sciences, Henan University, Kaifeng, Henan, 475004, People's Republic of China; ${ }^{3}$ Department of Chemistry, Quaid-I-Azam University, Islamabad 44000, Pakistan; ${ }^{4}$ Department of Chemistry, University of Sargodha, Sargodha 40100, Pakistan; ${ }^{5}$ School of Natural Sciences, National University of Science and Technology, Islamabad, 44000, Pakistan; ${ }^{6}$ Department of Pharmacy, Quaid-I-Azam University, Islamabad 44000, Pakistan; ${ }^{7}$ Department of Chemistry, University of Sargodha SubCampus, Bhakkar 30000, Pakistan; ${ }^{8}$ School of Basic Medical Sciences, Henan University College of Medicine, Henan 47500 I, People's Republic of China

Correspondence: Dong-Dong Wu Email ddwubiomed2010@163.com

Xin-Ying Ji

Email 10190096@vip.henu.edu.cn

\begin{abstract}
To look superior and acceptable in society, people from all over the world use various types of cosmetic products to enhance or alter their facial appearance and body texture. In recent times, an exponential surge in cosmetic use has been observed in Pakistan, and hence spending money on personal-care products is high. However, there are many reported facts about high loads of lead, mercury, copper, and others hazardous and cancerous elements in local Pakistani cosmetic brands. Consumers of these brands are at high risk of many clinical issues, including cancer. As such, it is a necessity to make people aware of the devastating harmful effects related to cosmetic use. The aim of this study was to provide information for stakeholders and raise awareness in the general public about the use of these local unauthorized personal-care cosmetic products, along with government strategies to stop this cosmetic blight on human health.
\end{abstract}

Keywords: cosmetics, cancer, health issues, mercury, Pakistan

\section{Introduction}

Cosmetics are products that are applied on external parts of the body to clean and protect, thus altering one's appearance or keeping those parts in good condition. Our external look plays a significant role in our daily social interactions, as a white complexion in many cultures is considered a mark of beauty in both men and women. General ingredients of cosmetics are formaldehyde, quaternium-15, heavy metals, methylchloroisothiazolinone, methylisothiazolinone, parabens, lanolin, colophonium, and p-phenylenediamine (PPD). Many of these ingredients are recognized as being safe or having a low toxicological contour, but others have concentrations of noxious chemicals that pose a significant risk of causing adverse reactions. ${ }^{1}$ Adverse effects of cosmetics are mostly reactions of the skin, such as contact dermatitis (allergic and irritant), phototoxic and photoallergic reactions, contact urticaria, and hypo/hyperpigmentation. However, possible adverse systemic effects have also been reported, eg, intoxication, lung dysfunction, and carcinogenic effects. ${ }^{2}$ For example, cosmetics with high level of lead and aluminum harm can result in juvenile delinquency and behavioral problems in children, while adulthood exposure to aluminum induces cholinotoxicity. ${ }^{3,4}$ Researchers have also confirmed that excessive use of these cosmetic items can disturb the hormones and lead to risks in pregnancy, with short gestational time in women and low sperm count in men. ${ }^{5-7}$ Due to greater practice, women are at more risk of acquiring hypersensitivity to ingredients of cosmetics than men. Whitening products used by women to keep their skin toned and beautiful contain hazardous substances for bleaching 
purposes, ie, hydroquinone, mercury, kojic acid, and vitamin $\mathrm{C}$, which can affect their health, and more dangerously these products are easily available in markets. ${ }^{8,9}$

Nowadays, toiletries and skin lightening (bleaching) are widely used all over the world especially in African and Asian countries, but there is a lack of public awareness about the right use of cutaneous creams in recommended quantities and their adverse effects on skin. ${ }^{10}$ Many quality-oriented cosmetic brands are positively regarded and favored by customers, but at the same time due to financial issues, most of the population is unable to afford those costly branded cosmetics. As such, they depend on local markets selling cheap, low-quality cosmetic items with such active ingredients as mercury, corticosteroids, and hydroquinone, which pose serious risks. ${ }^{11}$ It has been reported that impaired wound healing, fish-odor syndrome, steroid-addiction syndrome (exogenous), a broad spectrum of cutaneous wound infections, and endocrinological issues with corticosteroids (suppression of hypothalamicpituitary-adrenal axis) are associated with the use of these products. ${ }^{12}$ Although the skin provides a protective barrier, but certain ingredients and contaminants have the ability to penetrate the face, lips, or eyes and produce adverse local or systemic effects. ${ }^{13,14}$ Recently in Pakistan, an exponential surge in cosmetic products has been observed, where a person wears cosmetics to look superior and to be acceptable in society. Cosmetic-manufacturing units in Pakistan prompt the public to buy their products through electronic and print media. Pakistani women spend much money on purchasing personal-care grooming products and support the industry to grow more. ${ }^{15,16}$ According to one survey, Pakistanis spend Rs101 billion per year on personal-care products, ie, $4 \%$ of all household expenditure in the country. ${ }^{17}$ Unfortunately, in Pakistan these products are easily available at local stores, instead of only at pharmacies or at regular medical stores.

The majority of manufacturing units are unauthorized and working illegally on a large scale. According to a 2018 reports by a joint effort of the Ministry of Climate Change and the Sustainable Development Policy Institute, Islamabad, Pakistan, assessment of the quality of 59 local and international brand products revealed only three manufacturers were using standard mercury quantities, while the remaining 56 included excessive amounts $(0.74-44,292 \mathrm{ppm})$ in their products compared to the permissible 1ppm limit. ${ }^{18-21}$ A report by the European Environmental Bureau indicated that Pakistan exports many mercury-loaded toxic skin-whitening creams to countries like Bangladesh and the Philippines. ${ }^{22}$ According to a published report by the $\mathrm{BBC}$, trading centers had recently cracked on down many Pakistan brands, especially beauty creams, containing chemicals (hydroquinone, mercury, or corticosteroids) as core ingredients. ${ }^{23}$ In this study, we highlight the use of these cheaper and locally manufactured nonstandard cosmetics and the associated health risks by summarizing the available data from different sources, including scientific and government publications, newspaper articles, and other comparison studies on the commonest-used cosmetic items. We also report on some international brands that exceed hazard levels of noxious ingredients.

\section{Skin-Whitening Creams and Lotions}

Pakistan has been named among countries with high levels of mercury (third-most hazardous chemical) in various cosmetic products, in which skin-whitening creams come out on top of famous brands with highest sales. ${ }^{19}$ The use of skin-whitening creams for fair complexion was considered effective by a majority of women (59\%) in one study conducted in Pakistan, and they also agreed that a lighter skin tone was more beautiful and the use of skin-lightening products strongly associated with achieving a fair complexion. ${ }^{24}$ A Sustainable Development Policy Institute report has revealed the presence of high quantities of mercury and other heavy metals in skin-whitening creams found in Karachi, Lahore, Islamabad, Peshawar and other big cities of Pakistan. ${ }^{25}$ Most Pakistani cosmetic companies have high levels of mercury in their creams, facial lotions, and other skin-whitening products, which may pose a serious health risk to innocent customers. Tables 1 and 2 list both national and international brands of skin-whitening creams in Pakistan with high loads of deadly toxic chemicals. ${ }^{20}$

\section{Mehndi (Henna) and Black Mehndi Pakistani Brands}

Henna and black mehndi are widely used Pakistani products. There are 30-40 mehndi brands in Pakistani markets for which the details of the contained ingredients are totally absent. According to research from Karachi University, these products contain toxic chemicals (such as oxalic acid, sodium picramate, and titanium dioxide), textile dyes, carcinogenic substances, highly volatile organic solvents (camphor and terpineol), and other heavy metals, including PPD, lead, chromium, and nickel which not only cause allergic reactions but also penetrate blood vessels and damage body organs. ${ }^{26}$ Figure 1 illustrates PPD action on skin. 
Table I List of local skin-whitening creams containing high doses of mercury in Pakistan

\begin{tabular}{|c|c|c|c|c|}
\hline Number & Cream name & $\begin{array}{l}\text { Sample } \\
\text { ID }\end{array}$ & $\begin{array}{l}\mathrm{Hg} \\
\text { (ppm) }\end{array}$ & $\begin{array}{l}\text { Hg more } \\
\text { than } \\
\text { standard } \\
\text { (ppm) }\end{array}$ \\
\hline I & $\begin{array}{l}\text { Skin White milk } \\
\text { and haldi cream }\end{array}$ & IC-35 & 0.8 & $<20$ \\
\hline 2 & $\begin{array}{l}\text { Hemani Advance } \\
\text { herbal whitening } \\
\text { cream }\end{array}$ & $\mathrm{C} 0017$ & 2.59 & 159 \\
\hline 3 & $\begin{array}{l}\text { Goree beauty } \\
\text { cream }\end{array}$ & $\mathrm{C} 0012$ & 4.39 & 339 \\
\hline 4 & $\begin{array}{l}\text { Fair \& Lovely } \\
\text { advanced } \\
\text { multivitamin } \\
\text { (Pakistani) }\end{array}$ & $\mathrm{COOI}$ & 5.02 & 402 \\
\hline 5 & $\begin{array}{l}\text { Current Fairness } \\
\text { cream }\end{array}$ & $\mathrm{C} 0015$ & 8.45 & 745 \\
\hline 6 & $\begin{array}{l}\text { Hitone whitening } \\
\text { cream }\end{array}$ & $\mathrm{C} 0023$ & 9.11 & 811 \\
\hline 7 & $\begin{array}{l}\text { Skin White gold } \\
\text { beauty cream }\end{array}$ & LC-2I & 13.49 & $1.249 \times 10^{3}$ \\
\hline 8 & $\begin{array}{l}\text { Face Fresh } \\
\text { cleanser cream }\end{array}$ & LC-28 & 19 & $1.8 \times 10^{3}$ \\
\hline 9 & $\begin{array}{l}\text { Skin Clear } \\
\text { whitening cream }\end{array}$ & $\mathrm{C} 008$ & 21 & $2 \times 10^{4}$ \\
\hline 10 & $\begin{array}{l}\text { Gipsy with jojoba } \\
\text { oil }\end{array}$ & P-45 & 36.29 & $3.5 \times 10^{3}$ \\
\hline II & $\begin{array}{l}\text { Blush On beauty } \\
\text { cream }\end{array}$ & $\mathrm{C} 002$ & 65 & $6.4 \times 10^{3}$ \\
\hline 12 & $\begin{array}{l}\text { Permanent } \\
\text { whitening cream }\end{array}$ & $X-46$ & 128 & $1.2 \times 10^{4}$ \\
\hline 13 & $\begin{array}{l}\text { Whiteface } \\
\text { whitening cream }\end{array}$ & IC-34 & 324.7 & $3.2 \times 10^{4}$ \\
\hline 14 & $\begin{array}{l}\text { White Touch } \\
\text { whitening cream }\end{array}$ & $\mathrm{C} 0013$ & 1257 & $1.2 \times 10^{5}$ \\
\hline 15 & $\begin{array}{l}\text { Face Tonic } \\
\text { whitening formula }\end{array}$ & P-42 & 1,405 & $1.4 \times 10^{5}$ \\
\hline 16 & $\begin{array}{l}\text { CinciBrido } \\
\text { whitening cream }\end{array}$ & KC-37 & 1,479 & $1.479 \times 10^{5}$ \\
\hline 17 & $\begin{array}{l}\text { Nine Herbs } \\
\text { whitening cream }\end{array}$ & $\mathrm{C} 006$ & 2,420 & $2.41 \times 10^{5}$ \\
\hline 18 & Era beauty cream & $\mathrm{C} 007$ & 2,458 & $2.458 \times 10^{5}$ \\
\hline
\end{tabular}

(Continued)
Table I (Continued).

\begin{tabular}{|c|c|c|c|c|}
\hline Number & Cream name & $\begin{array}{l}\text { Sample } \\
\text { ID }\end{array}$ & $\begin{array}{l}\mathrm{Hg} \\
(\mathrm{ppm})\end{array}$ & $\begin{array}{l}\text { Hg more } \\
\text { than } \\
\text { standard } \\
\text { (ppm) }\end{array}$ \\
\hline 19 & $\begin{array}{l}\text { Alpha white } \\
\text { beauty cream }\end{array}$ & $\mathrm{C} 0016$ & 3,923 & $3.922 \times 10^{5}$ \\
\hline 20 & $\begin{array}{l}\text { Biocos emergency } \\
\text { whitening cream }\end{array}$ & $\mathrm{C} 002 \mathrm{I}$ & 5,129 & $5.128 \times 10^{5}$ \\
\hline 21 & $\begin{array}{l}\text { Dermolite } \\
\text { whitening cream }\end{array}$ & $\mathrm{C} 0019$ & 6,035 & $6.03 \times 10^{5}$ \\
\hline 22 & $\begin{array}{l}\text { Pure White } \\
\text { beauty whitening } \\
\text { cream }\end{array}$ & I.C-23 & 7,862 & $7.861 \times 10^{5}$ \\
\hline 23 & $\begin{array}{l}\text { Look Fresh beauty } \\
\text { cream }\end{array}$ & $|C-4|$ & 7,912 & $7.911 \times 10^{5}$ \\
\hline 24 & $\begin{array}{l}\text { Forever skin- } \\
\text { whitening cream }\end{array}$ & $\mathrm{C} 0014$ & 8,181 & $8.18 \times 10^{5}$ \\
\hline 25 & $\begin{array}{l}\text { Denso beauty } \\
\text { cream }\end{array}$ & $\mathrm{C} 009$ & 9,681 & $9.68 \times 10^{5}$ \\
\hline 26 & $\begin{array}{l}\text { White Secret } \\
\text { beauty cream }\end{array}$ & C004 & 10,369 & $1.03 \times 10^{6}$ \\
\hline 27 & $\begin{array}{l}\text { Sandal whitening } \\
\text { Beauty Cream }\end{array}$ & LC-27 & 12,044 & $1.2043 \times 10^{6}$ \\
\hline 28 & $\begin{array}{l}\text { Lead whitening } \\
\text { cream }\end{array}$ & $X-47$ & 13,658 & $1.3657 \times 10^{6}$ \\
\hline 29 & $\begin{array}{l}\text { Infocus pearl } \\
\text { beauty cream }\end{array}$ & $\mathrm{C} 0020$ & 14,493 & $1.4492 \times 10^{6}$ \\
\hline 30 & $\begin{array}{l}\text { White Face } \\
\text { whitening cream }\end{array}$ & LC-29 & 14,895 & $1.4895 \times 10^{6}$ \\
\hline 31 & $\begin{array}{l}\text { Sandal whitening } \\
\text { beauty cream }\end{array}$ & $\mathrm{C} 0018$ & 15,566 & $1.55 \times 10^{6}$ \\
\hline 32 & $\begin{array}{l}\text { Cherry skin- } \\
\text { whitening cream }\end{array}$ & C005 & 15,710 & $1.579 \times 10^{6}$ \\
\hline 33 & $\begin{array}{l}\text { White Gold } \\
\text { whitening } \\
\text { cream with } \\
\text { blackberry } \\
\text { extracts }\end{array}$ & LC-22 & 15,795 & $1.5794 \times 10^{6}$ \\
\hline 34 & $\begin{array}{l}\text { Zuni beauty cream } \\
\text { (female) }\end{array}$ & $\mathrm{C} 0010$ & 15,973 & $1.5972 \times 10^{6}$ \\
\hline 35 & $\begin{array}{l}\text { Maxdif skin- } \\
\text { brightening cream }\end{array}$ & $\mathrm{C} 0022$ & 16,004 & $1.6 \times 10^{6}$ \\
\hline
\end{tabular}

(Continued) 
Table I (Continued).

\begin{tabular}{|l|l|l|l|l|}
\hline Number & Cream name & $\begin{array}{l}\text { Sample } \\
\text { ID }\end{array}$ & $\begin{array}{l}\text { Hg } \\
\text { (ppm) }\end{array}$ & $\begin{array}{l}\text { Hg more } \\
\text { than } \\
\text { standard } \\
\text { (ppm) }\end{array}$ \\
\hline 36 & $\begin{array}{l}\text { Due whitening } \\
\text { cream }\end{array}$ & KC-50 & 16,805 & $1.6804 \times 10^{6}$ \\
\hline 37 & $\begin{array}{l}\text { Winsome } \\
\text { whitening beauty } \\
\text { cream }\end{array}$ & P-44 & 18,173 & $1.8172 \times 10^{6}$ \\
\hline 38 & $\begin{array}{l}\text { Zuni beauty cream } \\
\text { for men }\end{array}$ & C00II & 18,177 & $1.8176 \times 10^{6}$ \\
\hline 39 & $\begin{array}{l}\text { White Gold } \\
\text { whitening cream }\end{array}$ & C003 & 19,069 & $1.9068 \times 10^{6}$ \\
\hline 40 & $\begin{array}{l}\text { Delicate whitening } \\
\text { beauty cream }\end{array}$ & IC-39 & 23,780 & $2.3779 \times 10^{6}$ \\
\hline 41 & $\begin{array}{l}\text { Parley herbal } \\
\text { whitening cream }\end{array}$ & LC-29 & 40,131 & $4.013 \times 10^{6}$ \\
\hline
\end{tabular}

Notes: From a joint project of the Ministry of Climate Change and Sustainable Development Policy Institute, Islamabad, Pakistan. Results showed that most SWC brands had the potential to cause mercury toxicity effecting the general public health. Techniques used for mercury analysis were HGASS and ICP. ${ }^{19,25}$

\section{Black Stone (Kala Pathar)}

Due to low cost and easy availability, many Pakistani women opt to color their hair with black stone. Black stone's ingredients are very harmful and used as a poison for suicide. Major components of its composition are PPD, sodium, EDTA, and propylene glycol, which contribute to multiorgan failure. ${ }^{27}$ Excessive use of black stone may cause liver, respiratory system, and kidney problems. ${ }^{28}$

\section{Surma/Kajal}

Eye make-up in various cultures is favored by many, particularly women. In Pakistan, surma/kajal is a very popular eye cosmetic and widely used all over the country. It is a fine powder of heavy crystal or lead sulfides. Pakistani surma contains $0.03 \%-81.37 \%$ lead and it is highly toxic to the eyes. Lead penetrates into blood vessels and accumulates in the liver, thereby causing harmful diseases, including cancer. ${ }^{29}$ Applications of surma on umbilical stumps of newborns also plays an important role in increasing blood-lead levels in children from developing countries. ${ }^{30,34}$ Lining the eyes with surma/kajal, rubbing, and then licking the fingers enhances the absorption of lead, causing elevated bloodlead levels. ${ }^{31,32}$ The highest concentration of lead $(1,071 \mu \mathrm{g} / \mathrm{g})$ detected in surma was at Kohat market, Khyber Pakhtunkhwa, Pakistan. ${ }^{33}$ In various eye-makeup procedures, cosmetic products
Table 2 International skin-whitening creams in Pakistan with high volumes of mercury

\begin{tabular}{|c|c|c|c|}
\hline Number & Name of cream & $\begin{array}{l}\text { Sample } \\
\text { ID }\end{array}$ & $\begin{array}{l}\mathrm{Hg} \\
\text { (ppm) }\end{array}$ \\
\hline 1 & Co Natural whitening cream & $\mathrm{C} 0034$ & 1.88 \\
\hline 2 & Palmer's Skin Success & $\mathrm{C} 0035$ & 1.94 \\
\hline 3 & $\begin{array}{l}\text { Garnier Skin Naturals Speed } \\
\text { White }\end{array}$ & IC-38 & 1.98 \\
\hline 4 & $\begin{array}{l}\text { Garnier Light Complete White } \\
\text { Speed }\end{array}$ & $\mathrm{C} 0033$ & 2.11 \\
\hline 5 & Nivea Natural Fairness & $\mathrm{C} 0030$ & 4.2 \\
\hline 6 & Ponds white beauty cream & LC-25 & 5.01 \\
\hline 7 & Olay Natural White & $\mathrm{C} 0029$ & $5.4 I$ \\
\hline 8 & Olive whitening cream & $\mathrm{C} 0024$ & 8.31 \\
\hline 9 & $\begin{array}{l}\text { Garnier Skin Naturals White } \\
\text { Complete }\end{array}$ & LC-24 & 15.52 \\
\hline 10 & $\begin{array}{l}\text { Eveline Cosmetics White } \\
\text { Extreme, 3D }\end{array}$ & $\mathrm{C} 0032$ & 9.27 \\
\hline II & Stillman's skin bleach cream & IC-36 & 44,292 \\
\hline 12 & Fair and Lovely & P-43 & 40 \\
\hline 13 & Vince skin lightening night cream & $\mathrm{C} 0028$ & 21.35 \\
\hline 14 & $\begin{array}{l}\text { Fair and Lovely Max Fairness } \\
\text { Multi Expert face cream }\end{array}$ & IC-40 & 21 \\
\hline 15 & Ponds Flawless White & C003I & 0.74 \\
\hline 16 & YC whitening pearl cream & $\mathrm{C} 0025$ & 0.93 \\
\hline 17 & $\begin{array}{l}\text { Fair \& Lovely advanced } \\
\text { multivitamin }\end{array}$ & $\mathrm{C} 0026$ & 1.43 \\
\hline 19 & $\begin{array}{l}\text { Janssen Cosmetics brightening } \\
\text { night restore }\end{array}$ & $\mathrm{C} 0027$ & 1.82 \\
\hline
\end{tabular}

Notes: From a joint project of the Ministry of Climate Change and Sustainable Development Policy Institute, Islamabad, Pakistan. The results showed that most SWC brands had the potential to cause mercury toxicity, affecting both the skin and general public health. Techniques used for mercury analysis were HGASS and ICP. OES. ${ }^{19,25}$

can slip into the eyes and produce adverse effects on the ocular surface, ranging from mild discomfort to vision-threatening conditions. $^{34}$

\section{Pakistani Nail-Polish Brands}

Nail polish contains toxic aromatic chemicals, such as formaldehyde, toluene, and dibutyl phthalate. Formaldehyde is considered carcinogenic, and causes skin, eye, nose and throat irritation. Nail polish in Pakistan contains high 


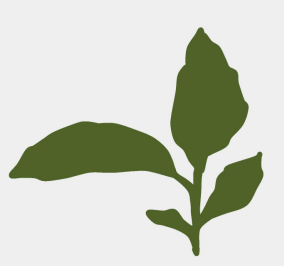

Henna plant leaves
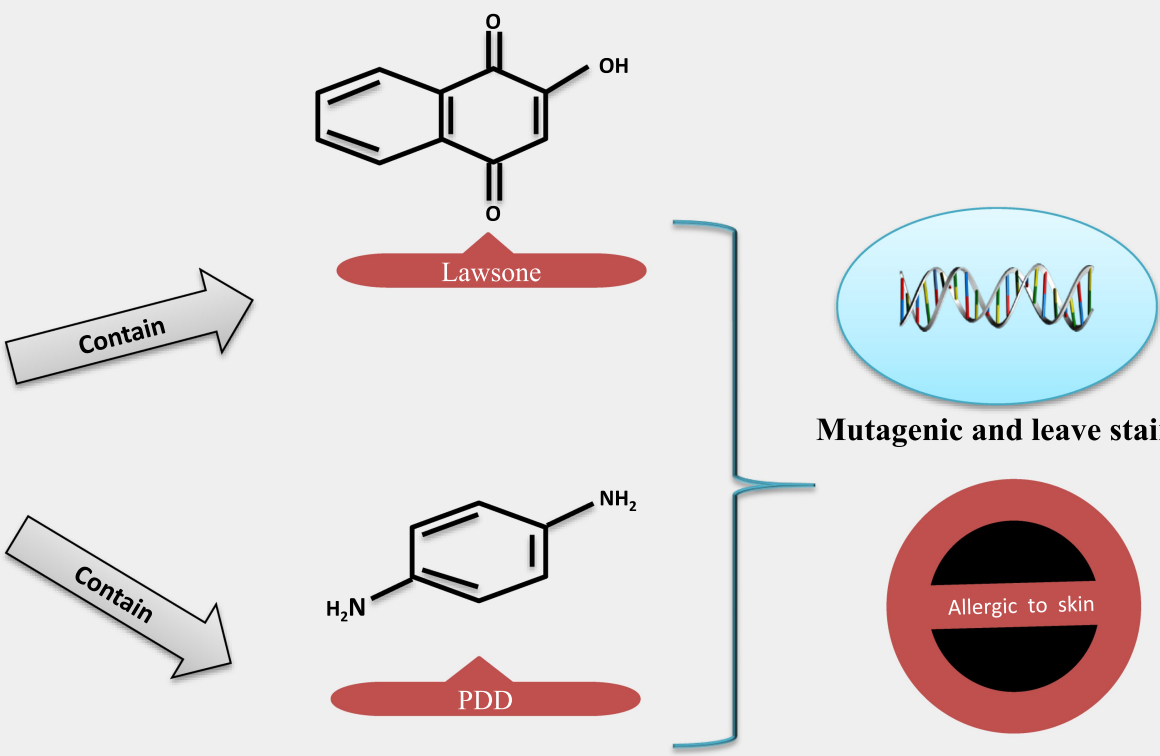

Mutagenic and leave stain
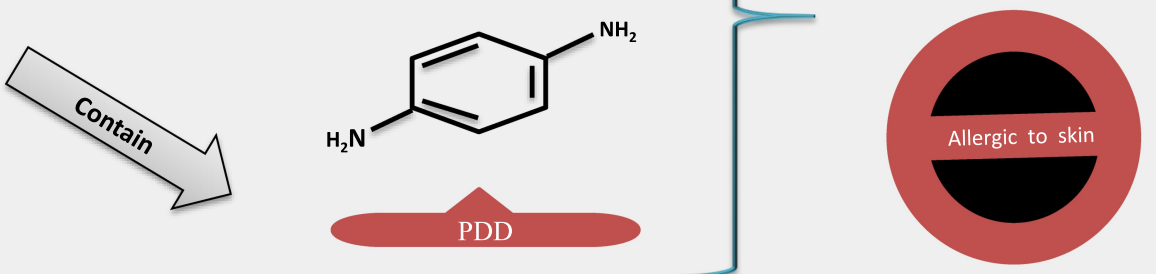

Allergic reactions on skin

Figure I Mutagenic effects of the henna plant and PPD action on skin. Leaves of the henna plant contain a red-orange dye (lawsone, also known as hennotannic acid) and PDD, which causes allergic and inflammatory reactions that develop carcinogenic effects. ${ }^{92,93}$.

quantity of toluene, which can be adsorbed into the skin through the nail beds, resulting in dizziness, headache, and fatigue. ${ }^{35}$ Arterial oxygen saturation level $\left(\mathrm{SpO}_{2}\right)$ in the blood is important for normal body physiology. Different nail polishes of different colors decrease $\mathrm{SpO}_{2}$ in the body and cause respiratory disorders, hypothermia, and other dysfunction. ${ }^{36}$ A Pakistani hair and skin cancer expert said that excessive use of nail polish can lead to dryness and weakening of nails, even discoloration. ${ }^{37}$

\section{Facial Hair and Cosmetics}

Having facial hair is a common and distressing problem for women. Laser therapy is a permanent solution to this. This treatment demands well-qualified, experienced, and skillful electrologists, but unfortunately unqualified and unscrupulous people in the country are using this methodology only for the sake of money. ${ }^{38}$ Many side effects have been reported with local facial creams to remove facial hair. Calcium hydroxide and potassium thioglycolate are present in hair-removal products. Such cosmetic items contain heavy metals that make the skin red and cause rashes on sensitive parts of the body, sexual and allergic problems, bed smell, and increase the risk of cancer. ${ }^{39}$

\section{Lipsticks}

A commonly cited aphorism is that "women accidentally eat about $4 \mathrm{lb}$ of lipsticks in a lifetime". Other than skin-whitening creams and lotions, lip cosmetics are more dangerous, as lips are more susceptible to absorption and present an oral route of exposure to chemicals. During drinking, eating, and kissing, one can ingest harmful ingredients of lipsticks. These products also increase levels of heavy metals, eg, lead, in the body. Lipsticks that contain high amounts of lead are very dangerous for pregnant women, because it can simply pass through the placenta. ${ }^{40}$ It has been found that some cosmetics markets in Khyber Pakhtunkhwa, Pakistan are selling lipsticks with high concentrations of $\mathrm{Fe}, \mathrm{Zn}, \mathrm{Pb}$, and $\mathrm{Cu}$. Prolonged use of such 
Table 3 Commonly used cosmetic items and their adverse consequences on consumer health

\begin{tabular}{|c|c|c|c|c|}
\hline Number & Cosmetics & Ingredients & Use & Side effects \\
\hline 1 & Lipsticks & $\begin{array}{l}\text { Manganese, lead, cadmium, } \\
\text { titanium dioxide, aluminum, } \\
\text { formaldehyde, and parabens }\end{array}$ & Volatile white and yellow colors & $\begin{array}{l}\text { Carcinogenic, renal failure, coughing, } \\
\text { and hazards in pregnancy } 40,41,43-45\end{array}$ \\
\hline 2 & Kohl (surma) & Lead sulfide & Darkening of eyelids & $\begin{array}{l}\text { Increased lead levels in blood and } \\
\text { damage to the liver }{ }^{30-34,46}\end{array}$ \\
\hline 3 & Nail polish & $\begin{array}{l}\text { Formaldehyde, nitrocellulose, } \\
\text { plasticizers, iron oxides, } \\
\text { manganese, benzophenone I }\end{array}$ & $\begin{array}{l}\text { Ticking agent, coloring agent, } \\
\text { and nonbrittle film to stop } \\
\text { bacterial or fungal infections in } \\
\text { cosmetics }\end{array}$ & $\begin{array}{l}\text { Nausea, respiratory problems, } \\
\text { cognitive and neurological symptoms, } \\
\text { uncontrollable muscle } \\
\text { contraction. }{ }^{35-37,47,48}\end{array}$ \\
\hline 4 & $\begin{array}{l}\text { Eye and facial } \\
\text { makeup, baby } \\
\text { wipes, and } \\
\text { household } \\
\text { detergents }\end{array}$ & $\begin{array}{l}\text { Diazolidinyl urea, DMDM, } \\
\text { methylisothiazolinone, } \\
\text { phenoxyethanol, mercury, copper, } \\
\text { titanium, tretinoin }\end{array}$ & $\begin{array}{l}\text { Cleanser, killing bacteria, slowing } \\
\text { and preventing spoilage, facial } \\
\text { expression }\end{array}$ & $\begin{array}{l}\text { Headaches, allergic reactions, burning } \\
\text { of skin, carcinogenic }^{49-51}\end{array}$ \\
\hline 5 & $\begin{array}{l}\text { Hair care, } \\
\text { moisturizers, } \\
\text { shaving products }\end{array}$ & $\begin{array}{l}\text { Parabens, salicylate, coloring } \\
\text { agents }\end{array}$ & $\begin{array}{l}\text { Preventing bacterial growth, } \\
\text { ultraviolet-light absorbance }\end{array}$ & $\begin{array}{l}\text { Skin irritation, blotches, } \\
\text { blemishes }^{39,52}\end{array}$ \\
\hline 8 & $\begin{array}{l}\text { Shampoo, body } \\
\text { soap, toothpaste }\end{array}$ & $\begin{array}{l}\text { Sodium sulfate and laureth sulfate, } \\
\text { fluoride, triclosan, } \\
\text { diethanolamine, triethanolamine }\end{array}$ & Cleansing and emulsifying agent & $\begin{array}{l}\text { Hair loss, breast cancer, skin } \\
\text { irritation, possible impurity } \\
\text { contamination }^{53}\end{array}$ \\
\hline 9 & $\begin{array}{l}\text { Aging and skin-care } \\
\text { products }\end{array}$ & $\begin{array}{l}\text { Beta-hydroxy-acids, } \\
\text { dihydroxyacetone, phthalates, } \\
\text { salicylic acid }\end{array}$ & $\begin{array}{l}\text { Improving skin texture, reducing } \\
\text { signs of aging, stopping harmful } \\
\text { ultraviolet radiation }\end{array}$ & $\begin{array}{l}\text { Effects in pregnancy, skin burning, } \\
\text { allergic reactions }{ }^{54}\end{array}$ \\
\hline 10 & $\begin{array}{l}\text { Face makeup, hair } \\
\text { products }\end{array}$ & $\begin{array}{l}\text { Diethanolamine, polyethylene } \\
\text { glycol }\end{array}$ & $\mathrm{pH}$ adjuster, foaming agent & $\begin{array}{l}\text { Skin irritation, contamination } \\
\text { concerns }^{52}\end{array}$ \\
\hline
\end{tabular}

products containing these elements may pose a threat to human health and the environment. ${ }^{33}$ Lipsticks containing toxic heavy metals can be ingested along with other cosmetics containing heavy metals through the oral pathway. ${ }^{41}$

\section{Skin-Whitening Soaps: Pakistani Brands}

Soaps and creams are skin-lightening products. Pakistan has many brands producing low quality soaps containing about $31 \mathrm{mg} / \mathrm{kg}$ and $33,000 \mathrm{mg} / \mathrm{kg}$ mercury and ammonium, respectively, that have serious effects on skin. ${ }^{42}$ There have been many reports about the lack of rules and regulation for manufacturers of cosmetic items in Pakistan, yet the public continues to expose themselves to carcinogenic ingredients in personal-care products like shampoo, soaps, surma, and lipstick. Table 3 summarizes commonly used cosmetic items and their adverse consequence on consumer health.

\section{Topical Steroids and Bleaching Creams}

In Pakistan, different strategies and cosmetic materials are used for treatment and prevention of aging and to keep the skin toned. Most cosmetic items contain hydroquinone, mercury, and vitamin $\mathrm{C}$ as functional ingredients for bleaching and antiaging purposes. ${ }^{8}$ According to a study on the magnitude of both topical steroid and whitening-cream abuse in steroidal rosacea patients, $33 \%$ were using potent topical steroids and $17 \%$ patients whitening creams exclusively, while the other $50 \%$ were using topical steroids in combination with various whitening creams that base the steroidal dermatitis. ${ }^{55}$

\section{Cosmetics and Cancer}

Cosmetic products and increased cancer risk are subjects of controversy nowadays, eg, associations between parabens and breast cancer, hair dyes and hematologic malignancies, and talc powders and ovarian cancer. According 
to the Center for Food Safety and Applied Nutrition Adverse Event Reporting System database, there are nine unique cancers associated with hair products, of which only chronic lymphocytic leukemia, lung cancer, and breast cancer have been reported in the literature. ${ }^{56}$ Due to their chemical similarity to asbestos, talc products cause ovarian cancer in occupational settings and through migration of talc to the ovaries through the vagina. It is estimated that $14 \%$ of women with ovarian cancer have some talc exposure, while skin moisturizers make up only $10.5 \%$ of total cancer cases. ${ }^{57}$ Many studies have proved the role of parabens, used as preservatives in cosmetics, in breast cancer. $^{58-60}$ Exposure to hair dyes increases the chances of leukemia, non-Hodgkin's lymphomas, and bladder cancer. $^{60-63}$ In another study, it has been reported that personal use of darker hair dyes and relaxants are involved in estrogen receptor-positive and estrogen-receptor breast cancer. ${ }^{64}$ Moreover, the use of other hair products has a significant correlation with cancer risk factors. In 2011, the FDA issued warning letters to designers of a certain heated hair treatment, Brazilian Blowout, due to the release of formaldehyde with heat. Formaldehyde is a known carcinogen associated with lung and hematologic malignancies. ${ }^{65-67}$ Figure 2 shows the association of haircoloring products with different cancers.

Research has revealed that there is an increased chance of cancer after exposure to genotoxic metals, such as chromium VI, cobalt, and nickel, in cosmetic products. $^{68-73}$ In other studies, heavy metals, such as lead, cadmium, and chromium, in pigments of lipstick, eye shadow, lip makeup, and face powder may lead to cancerous and noncancerous effects on human health. ${ }^{70,74}$ Use of commercially available moisturizing creams increases the chances of tumor formation when applied topically to UVB-pretreated high-risk mice. ${ }^{75}$ It has been found that cosmetic and fragranced products pose high risks of breast cancer and other illnesses. ${ }^{76}$ Due to bodycare cosmetics' role in breast cancer incidence, consumers should adopt precautionary principles about these products (including moisturizers, creams, sprays, or lotions applied to axilla, chest, or breast areas). Oncologists have great concern for consumers of such toxin-contaminated personal-care items, and they are trying to uncover possible mechanisms involved in the carcinogenic effects of cosmetics. To deal with this association of cancer risks and personal-care products, there must be better and broader

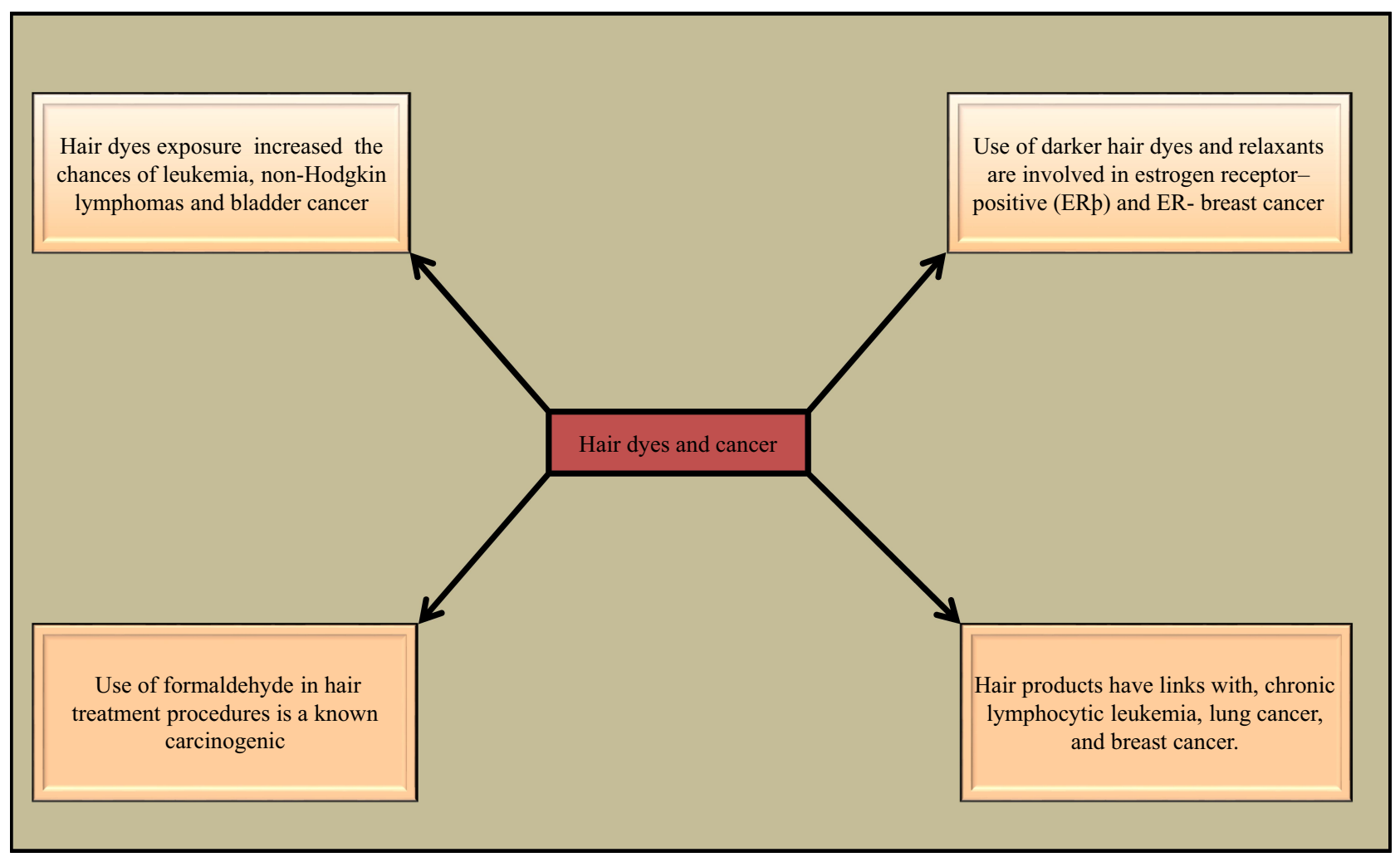

Figure 2 Associations between hair-coloring products and cancer risks. The Hair-dye ingredients increase the risks of different cancer types, such as leukemia, lung, breast, and skin. 
data collection that can highlight the emerging concerns and direct scarce regulatory resources toward promoting public safety and relieving consumer fears.

\section{Cosmetics and the Environment}

Detrimental ingredients in cosmetics not only affect consumer health but are also a burden on the environment and consequently all life. Most lethal ingredients, ie, parabens are used to increase the shelf life and quality of cosmetics. There is great concern about the presence of these parabens released from cosmetic vials in the open environment and their postuse processing by the plastics industry into drinking water and the air (dust). ${ }^{77-79}$ The major source of this ubiquitous occurrence of parabens in the environment is wastewater-treatment plants. ${ }^{80}$ This postuse mixing of cosmetic ingredients is very alarming, as they pose potential problems to aquatic life and human after being deposited in bodies of water. ${ }^{81}$ Cosmetics with high mercury content are eventually discharged into wastewater after usage, and mercury becomes methylated and enters the food chain in the form of methylmercury, which is highly toxic to fish. Pregnant woman who consume fish containing methylmercury transfer the mercury to their fetuses, which leads to neurodevelopmental and other illnesses in the children. ${ }^{82,83}$ Due to its undegradable nature, plastic packaging of cosmetics also plays a substantial role in poisoning our ecosystem. According to recent estimates, 600 million plastic bags, including cosmetic plastics, are used each hour in the world. ${ }^{84}$ According to research from Karachi University, commonly used nonstandard cosmetic products comprise such chemicals as oxalic acid, sodium picramate, and titanium dioxide, textile dyes, carcinogenic substances, highly volatile organic solvents (camphor and terpineol) and other heavy metals, eg, lead, chromium and nickel. Excessive use of these products has the potential to damage consumer health and cause accretion of toxic metals in the environment. ${ }^{85}$

\section{Cosmetic Regulation in Pakistan}

Pakistan is one of several countries that needs to modernizing its drugs and cosmetic products in this climate of global change. Presently, there do not seem to be effective checks and balances in place, and specific regulations on standards for chemicals (like mercury) in consumer products, including cosmetics and skinwhitening creams, are much needed. Many official government-institute reports and scientific papers have appealed to the government of Pakistan to take the necessary steps toward regulation of cosmetic products in the country. As a signatory to the Minamata Convention on Mercury and with a growing network of unauthorized, illegally marketed cosmetic products, the government of Pakistan is working hard to achieve objectives to streamline authorization of a pure-cosmetic supply chain in the market. Pakistan is trying to strengthen relevant institutes like the Pakistan National Accreditation Council, Pakistan Standards and Quality Control Authority (PSQCA), Drug Regulatory Authority of Pakistan to implement a quality-management system for regulation of the manufacture, import, sale, and distribution of all cosmetic products. The Ministry of Science and Technology has issued a law to regulate skin creams all over Pakistan through the PSQCA, whereby a special task force will check manufacturing units, markets, and stores to highlight substandard cosmetics and take strict legal action. ${ }^{86}$ Authorities have started the cancellation of licenses and sealing manufacturing unit whose products do not meet the standards of the PSQCA. ${ }^{87}$ Furthermore, the Punjab government has approved a Drug and Cosmetics Amendment Act by which all cosmetic-sale points will need to be licensed for the provision of genuine products through the original supply chain. ${ }^{88}$

With some amendments as necessary to take account of regulations as per the requirements of the country, Pakistan is in in urgent need of adopting the most reliable model on regulation - that of Cosmetics Europe. This represents the European cosmetic industry, and has developed new requirements and guidelines to promote consistent procedures for the management of reporting serious undesirable effects from the use of personal-care cosmetic products to competent authorities. ${ }^{89,90}$ These guidelines are mutual outcomes of discussions with international competent authorities, industry, and other interested parties in the market-surveillance sector. ${ }^{91}$ Following these guidelines, an appropriate management system will be set up to phase out all illegal brands from the market and and thus fulfill legal obligations under cosmetics regulations, take responsibility for cosmetic products, and ensure that appropriate action can be taken. At present, these guidelines are an evolution of earlier industry guidelines on the management of cosmetic-industry products to become free of harmful ingredients. 


\section{Recommendations}

There is a dire need for combined action by all relevant and responsible stakeholders, including the government, to monitor and keep strict checks and balances on manufacturers of local and imported cosmetic products in the country. The lethality of these toxic cosmetic products is a public problem, and there is a need to raise awareness among all consumers. There is an effective and broad role to be played by all electronic and print media in changing misleading and outdated concepts of attractiveness, appeal, and, beauty.

All consumer products need to be have proper labels (mandatory), clearly indicating the amount of chemicals added to the products, with updated contact information for the manufacturers. Consumer products containing excessive amounts of chemicals need to be banned for use/sale/manufacturing, and strict rules should be there to discourage manufactureres from playing with lives. There should be strong decisions by consumer courts to regulate ingredient labeling on each product. People should avoid purchasing foreign brands if the ingredients are not printed in English. To improve the appearance of aged skin, products of good brands recommended by dermatologists should be used, and dermatologists must analyze anatomical variants and hormonal and genetic factors related to aging. There must be rules for advertising approved cosmetic products. Environmental protection agencies may also be involved, in view of environmental pollution caused by chemical use and resulting release/ waste. It is also recommended that the Higher Education Commission looks into MBBS syllabi/curricula for needed additional information about cosmetics, especially skinwhitening creams, to be included for dermatology specialization. Figure 3 shows directions to protect consumers from the effects of hazardous, unauthorized personal-care cosmetic products.

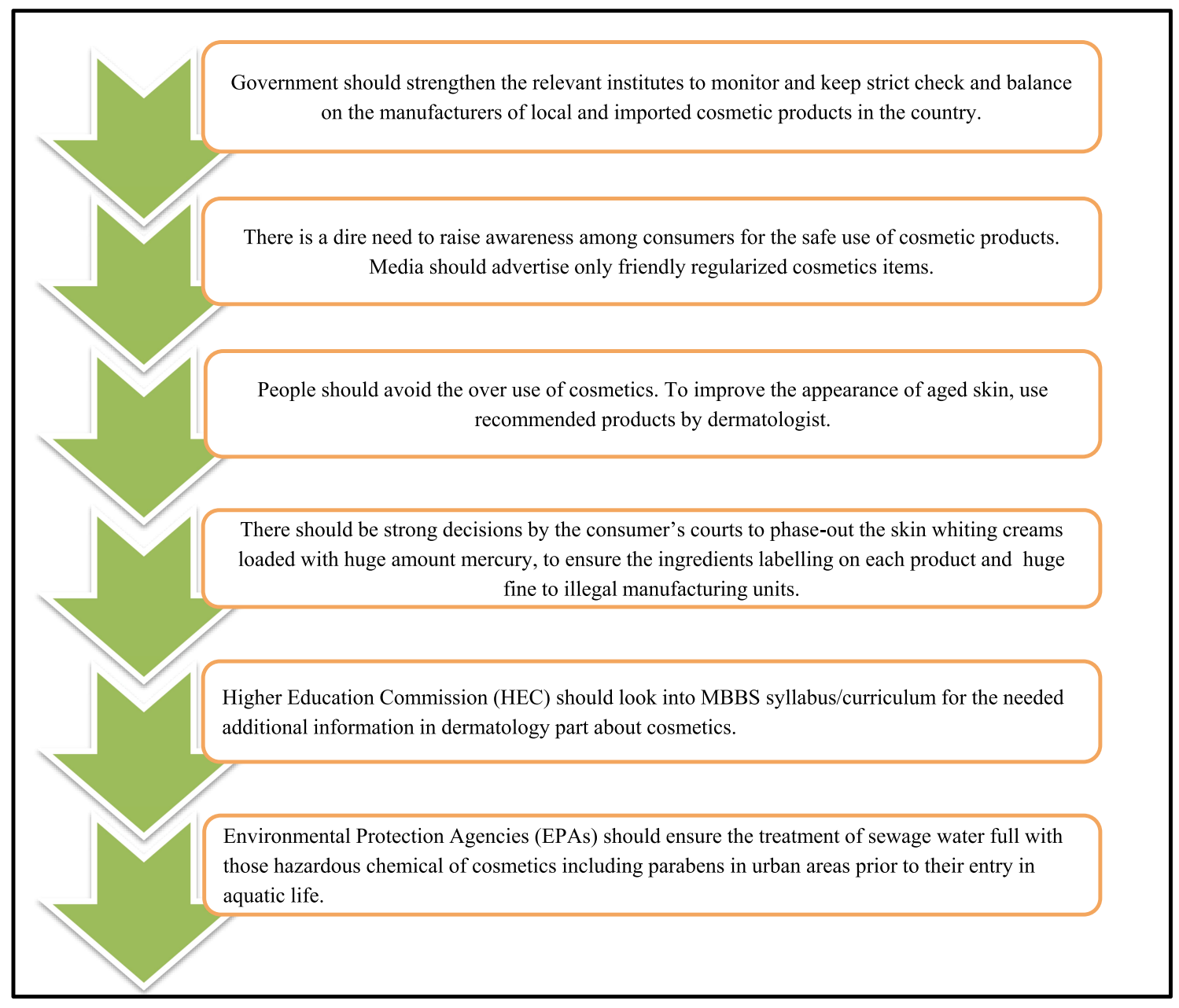

Figure 3 Directions to save cosmetic consumers from the effects of hazardous, unauthorized personal-care cosmetic products. 


\section{Conclusion}

Low-quality, unauthorized cosmetic products have adverse effects on consumer health and cause serious medical complications. Due to the open availability of illegally manufactured cosmetic items at local stores, a large portion of the Pakistani population - both men and women, urban and rural - has been severely affected with facial skin damage and other clinical health issues. People have no knowledge about associations of ingredients with skin rupture, carcinogenesis, or multiorgan failure. They are exposing themselves to toxic chemicals continuously and unknowingly in the pursuit of beauty. There is an urgent need to address the problems highlighted and employ checks and balances in the country to thoroughly evaluate and regulate all personal-care cosmetic products prior to their marketing. The general public must be aware of the consequences of buying unauthorized, toxic cosmetics, and the government should ensure a standard supply chain into markets with safety data for all local and imported items.

\section{Data-Sharing Statement}

All the data used in this review have been presented in the main text as either tables or figures. Additional requests for the data can be made electronically. Please email kakakhan3514@gmail.com

\section{Ethics Approval}

Not applicable.

\section{Acknowledgment}

The authors gratefully acknowledge the assistance and motivation energy of Dr. Muhammad Sarfaraz to accomplish this manuscript. Authors also pay thanks to Dr. Attia Afzal for their valuable comments on the manuscript. Hussain is deeply gratified to his Piayree Lala, who drives him to do great services.

\section{Funding}

The authors appreciate and acknowledge the financial support from the Natural Science Foundation of Henan Province (162300410044).

\section{Disclosure}

The authors declare that they have no conflicts of interest for this work.

\section{References}

1. White IR, de Groot AC. Cosmetics and skin care products. Contact Dermatitis. 2006;p. 493-506.

2. Schliemann S. Adverse effects of skin protective products, including sunscreens. Kanerva's Occupational Dermatol. 2020;731-736.

3. Chauhan AS, Bhadauria R, Singh AK, Lodhi SS, Chaturvedi DK, Tomar VS. Determination of lead and cadmium in cosmetic products. J Chem Pharm Res. 2010;2(6):92-97.

4. Al-Dayel O, Hefne J, Al-Ajyan T. Human exposure to heavy metals from cosmetics. Oriental J Chemistry. 2011;27(1):1-11.

5. Marie C, Cabut S, Vendittelli F, Sauvant-Rochat M-P. Changes in cosmetics use during pregnancy and risk perception by women. Int J Environ Res Public Health. 2016;13(4):383. doi:10.3390/ ijerph13040383

6. Li H, Zheng J, Wang H, et al. Maternal cosmetics use during pregnancy and risks of adverse outcomes: a prospective cohort study. Sci Rep. 2019;9(1):1-8.

7. Reseacher S. Chemicals in cosmetics can cause infertility. Global IVF; 2017. Available from: (https://globalivf.com/2017/04/17/chemi cals-in-cosmetics-can-cause-infertility/).

8. Amponsah D, Sebiawu GE, Voegborlo R. Determination of amount of mercury in some selected skin-lightening creams sold in the Ghanaian market. Int $J$ Eng Res. 2014;3:6.

9. Agorku ES, Kwaansa-Ansah EE, Voegborlo RB, Amegbletor P, Opoku F. Mercury and hydroquinone content of skin toning creams and cosmetic soaps, and the potential risks to the health of Ghanaian women. Springer Plus. 2016;5(1):319. doi:10.1186/s40064-016-1967-1

10. Burger P, Landreau A, Azoulay S, Michel T, Fernandez X. Skin whitening cosmetics: feedback and challenges in the development of natural skin lighteners. Cosmetics. 2016;3(4):36. doi:10.3390/cosmetics3040036

11. Khan S, Ahmad SY, Saleem S. Customer Perception towards Imported Cosmetics. European J Business Management. 2014;6 (28):202-204.

12. Olumide YM, Akinkugbe AO, Altraide D, et al. Complications of chronic use of skin lightening cosmetics. Int J Dermatol. 2008;47 (4):344-353. doi:10.1111/j.1365-4632.2008.02719.x

13. Loretz L, Api A, Babcock L, et al. Exposure data for cosmetic products: facial cleanser, hair conditioner, and eye shadow. Food Chem Toxicol. 2008;46(5):1516-1524. doi:10.1016/j.fct.2007.12.011

14. Nohynek GJ, Antignac E, Re T, Toutain H. Safety assessment of personal care products/cosmetics and their ingredients. Toxicol Appl Pharmacol. 2010;243(2):239-259. doi:10.1016/j.taap.2009.12.001

15. Ahmed R, Siddiqui K. Beauty parlor business in Pakistan: problems \& prospects. Asian J Research Marketing. 2013;2(4):55.

16. Fatima S, Lodhi S. Impact of advertisement on buying behaviours of the consumers: study of cosmetic industry in Karachi City. Int j Management Sci Business Res. 2015.

17. GALLUP. Hair care study, findigs from a national study. PIRANA; 2010. Available from: athttp://gallup.com.pk/wp-content/uploads/ 2015/02/Hair-Care-Study-Report.pdf.

18. Reporter S. The ministry of climate change is cracking down on dangerous fairness creams. image Magzine; 2019. Available from: https:// images.dawn.com/news/1183337. Accessed November 16, 2020.

19. Bushra Afzal SR, Waqar Ali S, Abbas Z, Mahmood A, K. Mercury poisoning associated with international and local skin whitening creams in Pakistan. Ministry of Climate Change (MOCC), Sustainable Development Policy Institute (SDPI) Islamabad, Pakistan. Available from: https://www.think-asia.org/bitstream/handle/11540/9423/ MercuryPoisoningAssociatedwithInernationalandLocalSkinWhiteningr eamsinPakistan.pdf? sequence=1. 2018 .

20. FDA FaDA. Prohibited \& restricted ingredients in cosmetics by FDA regulations. Cosmetics and USA laws; 2020. Available from: https:// www.fda.gov/cosmetics/cosmetics-laws-regulations/prohibitedrestricted-ingredients-cosmetics. Accessed November 16, 2020. 
21. Mercury) MMCo. United Nations environment programme Minamata Convention on Mercury; 2013. Available from: http:// www.mercuryconvention.org/. Accessed November 16, 2020.

22. Andreas Prevodnik AWEL-S, Bender, M. MERCURY- ADDED SKIN-LIGHTENING CREAMS Available, inexpensive and toxic. European Environmental Bureau (EEB). 2018.

23. Ahmed H. UK Fines Pakistani beauty products for using cancerous chemicals. proPakistani News Agancy; 2017. Available from: https:// propakistani.pk/2017/01/16/popular-face-whitening-creams-fined-forusing-cancer-causing-chemicals/. Accessed November 16, 2020.

24. Hamed SH, Tayyem R, Nimer N, AlKhatib HS. Skin-lightening practice among women living in Jordan: prevalence, determinants, and user's awareness. Int $J$ Dermatol. 2010;49(4):414-420. doi:10.1111/j.1365-4632.2010.04463.x

25. SWA MAK. Assessment of prevalence of health complications and skin diseases due to mercury containing Skin Whitening Creams (SWCs) use among the population at selected cities of pakistan. sustainable development policy institute (SDPI) Islamabad Pakistan. Available from: https://think-asia.org/bitstream/handle/11540/9423/ MercuryPoisoningAssociatedwithInernationalandLocalSkinWhitenin greamsinPakistan.pdf? sequence=1. 2016.

26. Ilyas F. KARACHI: chemically-laced mehndi in widespread use. Dawn News Agency. 2008.

27. Abbas M, Noor M, AA K. Hair dyes (black stone) toxicity and its complications. Pakistan J Med Health Sci. 2017;50(25)

28. Umair SF, Amin I, Urrehman A. Hair dye poisoning:"an early intervention". Pakistan J Med Sci. 2018;34(1):230. doi:10.12669/ pjms.341.14123

29. Rahbar MH, White F, Agboatwalla M, Hozhabri S, Luby S. Factors associated with elevated blood lead concentrations in children in Karachi, Pakistan. Bull World Health Organ. 2002;80:769-775.

30. Tiffany-Castiglioni E, Barhoumi R, Mouneimne Y. Kohl and surma eye cosmetics as significant sources of lead $(\mathrm{Pb})$ exposure. J Local Global Health Science. 2012;2012(1):1. doi:10.5339/jlghs.2012.1

31. Goswami K. Eye cosmetic 'surma': hidden threats of lead poisoning. Indian J Clin Biochem. 2013;28(1):71-73. doi:10.1007/s12291-0120235-6

32. Ikegami A, Takagi M, Fatmi Z, et al. External lead contamination of women's nails by surma in Pakistan: is the biomarker reliable? Environ Pollut. 2016;218:723-727. doi:10.1016/j.envpol.2016.07.068

33. Ullah H, Noreen S, Rehman A, et al. Comparative study of heavy metals content in cosmetic products of different countries marketed in Khyber Pakhtunkhwa, Pakistan. Arabian J Chem. 2017;10(1):10-18. doi:10.1016/j.arabjc.2013.09.021

34. Coroneo MT, Rosenberg ML, Cheung LM. Ocular effects of cosmetic products and procedures. Ocul Surf. 2006;4(2):94-102. doi:10.1016/S1542-0124(12)70031-9

35. Doheny K. Is your nail polish toxic? reseacher find toxic in nail polish labeled ttoxin- free; industry says report lacks perspective Radiance by WebMD; 2012. A vailable from: https://www.webmd. com/beauty/news/20120411/is-your-nail-polish-toxic\#1. Accessed November 16, 2020.

36. Haq A, Zafar K, Fatima M, Shafique M Effects of different nail polish colors on arterial blood oxygen saturation values (spo2) in pakistani population. Proceedings of the 2018 3rd International Conference (University of Bari,Italy) on Biomedical Imaging, Signal Processing; 2018; 2018. p. 6-9.

37. Qazi MA. Is nail polish bad for your nails? FHM Pakistan; 2019. Available from: https://www.fhmpakistan.com/fhm-breeze/is-nailpolish-bad-for-your-nails/. Accessed November 16, 2020.

38. Reporter S Electrolysis: hairy dilemma. Dawn News Agency; 2011. Available from: https://www.dawn.com/news/635938/electrolysishairy-dilemma. Accessed November 16, 2020.

39. Bukhari IH. Determination and toxicological effects of metals on human skin by using hair removing creams and lotions by spectroscopic techniques. Int Res J Pharm Appl Sci. 2013;3(4):9-11.
40. Martinez PA Is wearing lipstick bad for your pregnancy? August 20, 2013.Available from: https://www.parents.com/pregnancy/every thing-pregnancy/is-wearing-lipstick-bad-for-your-pregnancy/. Accessed November 16, 2020. Parents.

41. Brown VJ. Metals in lip products-a cause for concern? National Institute Environmental Health Sci. 2013.

42. WHO WHO. Mercury in skin lightening products. Preventing Disease Through Healthy Environments; 2019. Available from: https://www.who.int/publications/i/item/WHO-CED-PHE-EPE-19. 13. Accessed November 16, 2020.

43. Ziarati P, Moghimi S, Arbabi-Bidgoli S, Qomi M. Risk assessment of heavy metal contents (lead and cadmium) in lipsticks in Iran. Int J Chem Eng Appl. 2012;3(6):450. doi:10.7763/IJCEA.2012.V3.241

44. Malvandi H, Sancholi F. Assessments of some metals contamination in lipsticks and their associated health risks to lipstick consumers in Iran. Environ Monit Assess. 2018;190(11):680. doi:10.1007/s10661018-7065-9

45. Zakaria A, Ho YB. Heavy metals contamination in lipsticks and their associated health risks to lipstick consumers. Regulatory Toxicol Pharmacol. 2015;73(1):191-195. doi:10.1016/j.yrtph.2015.07.005

46. Al-Hazzaa SA, Krahn PM. Kohl: a hazardous eyeliner. Int Ophthalmol. 1995;19(2):83-88. doi:10.1007/BF00133177

47. Ouremi OI, Ayodele OE. Lipsticks and nail polishes: potential sources of heavy metal in human body. Int J Pharm Res Allied Sci. 2014;3(4):45.

48. Felzenszwalb I, da Silva Fernandes A, Brito LB, et al. Toxicological evaluation of nail polish waste discarded in the environment. Environ Sci Pollution Res. 2019;26(27):27590-27603.

49. Nnorom I, Igwe J, Oji-Nnorom C. Trace metal contents of facial (make-up) cosmetics commonly used in Nigeria. African J Biotechnol. 2005;4(10).

50. Suskind R, Meister M, Scheen S, Rebello D. Cutaneous effects of household synthetic detergents and soaps. Arch Dermatol. 1963;88 (2):117-124. doi:10.1001/archderm.1963.01590200005001

51. Odio M, Streicher-Scott J, Hansen RC. Disposable baby wipes: efficacy and skin mildness. Dermatology Nursing. 2001;13(2):107.

52. Toosi P, Sadighha A, Sharifian A, Razavi GM. A comparison study of the efficacy and side effects of different light sources in hair removal. Lasers Med Sci. 2006;21(1):1-4. doi:10.1007/s10103-006-0373-2

53. Bondi CA, Marks JL, Wroblewski LB, Raatikainen HS, Lenox SR, Gebhardt KE. Human and environmental toxicity of sodium lauryl sulfate (sls): evidence for safe use in household cleaning products. Environ Health Insights. 2020;9(1).

54. Allemann IB, Baumann L. Antioxidants used in skin care formulations. Skin Therapy Lett. 2008;13(7):5-9.

55. Chohan SN, Suhail M, Salman S, et al. Facial abuse of topical steroids and fairness creams: a clinical study of 200 patients. J Pakistan Association Dermatol. 2016;24(3):204-211.

56. Jacob SL, Cornell E, Kwa M, Funk WE, Xu S. Cosmetics and cancer: adverse event reports submitted to the food and drug administration. JNCI Cancer Spectrum. 2018;2(2):pky012. doi:10.1093/jncics/ pky012

57. Harlow BL, Cramer DW, Bell DA, Welch WR. Perineal exposure to talc and ovarian cancer risk. Obstet Gynecol. 1992;80(1):19-26.

58. Charles AK, Darbre PD. Combinations of parabens at concentrations measured in human breast tissue can increase proliferation of MCF-7 human breast cancer cells. J Appl Toxicol. 2013;33(5):390-398. doi: $10.1002 /$ jat. 2850

59. Barr L, Metaxas G, Harbach C, Savoy L, Darbre P. Measurement of paraben concentrations in human breast tissue at serial locations across the breast from axilla to sternum. J Appl Toxicol. 2012;32 (3):219-232. doi:10.1002/jat.1786

60. Couto AC, Ferreira JD, Rosa AC, Pombo-de-Oliveira MS, Koifman S, Leukemia B. Pregnancy, maternal exposure to hair dyes and hair straightening cosmetics, and early age leukemia. Chem Biol Interact. 2013;205(1):46-52. doi:10.1016/j.cbi.2013.05.012 
61. Bolt HM, Golka K. The debate on carcinogenicity of permanent hair dyes: new insights. Crit Rev Toxicol. 2007;37(6):521-536. doi:10.1080/10408440701385671

62. De Sanjosé S, Benavente Y, Nieters A, et al. Association between personal use of hair dyes and lymphoid neoplasms in Europe. $\mathrm{Am}$ J Epidemiol. 2006;164(1):47-55. doi:10.1093/aje/kwj187

63. Huncharek M, Kupelnick B. Personal use of hair dyes and the risk of bladder cancer: results of a meta-analysis. Public Health Rep. 2005;120(1):31-38. doi:10.1177/003335490512000107

64. Llanos AA, Rabkin A, Bandera EV, et al. Hair product use and breast cancer risk among African American and White women. Carcinogenesis. 2017;38(9):883-892. doi:10.1093/carcin/bgx060

65. Hauptmann M, Lubin JH, Stewart PA, Hayes RB, Blair A. Mortality from lymphohematopoietic malignancies among workers in formaldehyde industries. J Natl Cancer Inst. 2003;95(21):1615-1623. doi:10.1093/jnci/djg083

66. Maneli MH, Smith P, Khumalo NP. Elevated formaldehyde concentration in "Brazilian keratin type" hair-straightening products: A cross-sectional study. $J$ Am Acad Dermatol. 2014;70(2):276-280. doi:10.1016/j.jaad.2013.10.023

67. Schwilk E, Zhang L, Smith MT, Smith AH, Steinmaus C. Formaldehyde and leukemia: an updated meta-analysis and evaluation of bias. J Occupational Environmental Med. 2010;52 (9):878-886. doi:10.1097/JOM.0b013e3181ef7e31

68. Barbosa JF. Toxicology of metals and metalloids: promising issues for future studies in environmental health and toxicology. J Toxicol Environ Health A. 2017;80(3):137-144. doi:10.1080/15287394.2016.1259475

69. Lim H, Lim J-A, Choi JH, et al. Associations of low environmental exposure to multiple metals with renal tubular impairment in korean adults. Toxicol Res. 2016;32(1):57-64. doi:10.5487/ TR.2016.32.1.057

70. Ruiz LR, LdRV O, de Oliveira TSB, et al. Investigation of the presence of heavy metals and other contaminants in labor cosmetics and their health risks in general. Health Sci J. 2019;13(3):1-3.

71. Ly SY, Lee CH, Koo JM. Detection of toxic heavy metal, co (ii) trace via voltammetry with semiconductor microelectrodes. Toxicol Res. 2017;33(2):135-140. doi:10.5487/TR.2017.33.2.135

72. Mustapha MK. Dynamics of hexavalent chromium in four types of aquaculture ponds and its effects on the morphology and behavior of cultured Clarias gariepinus (Burchell 1822). Toxicol Res. 2017;33 (2):119-124. doi:10.5487/TR.2017.33.2.119

73. Wultsch G, Nersesyan A, Kundi M, et al. Genotoxic and cytotoxic effects in exfoliated buccal and nasal cells of chromium and cobalt exposed electroplaters. J Toxicol Environ Health A. 2017;80(13-15):651-660. doi:10.1080/15287394.2017.1286918

74. Lim DS, Roh TH, Kim MK, et al. Non-cancer, cancer, and dermal sensitization risk assessment of heavy metals in cosmetics. $J$ Toxicol Environ Health A. 2018;81(11):432-452.

75. Lu Y-P, Lou Y-R, Xie J-G, et al. Tumorigenic effect of some commonly used moisturizing creams when applied topically to UVB-pretreated high-risk mice. J Investigative Dermatol. 2009;129 (2):468-475. doi:10.1038/jid.2008.241

76. Coleman JW. Cosmetics and Fragranced Products Pose High Risks for Breast Cancer and Other Illnesses. Cancer Research Center of America, Inc; 2013.

77. Peregrino CP, Moreno MV, Miranda SV, Rubio AD, Leal LO. Mercury levels in locally manufactured Mexican skin-lightening creams. Int $J$ Environ Res Public Health. 2011;8(6):2516-2523. doi:10.3390/ijerph8062516
78. Ferreira AMC, Möder M, Laespada MEF. GC-MS determination of parabens, triclosan and methyl triclosan in water by in situ derivatisation and stir-bar sorptive extraction. Anal Bioanal Chem. 2011;399 (2):945-953.

79. Canosa P, Pérez-Palacios D, Garrido-López A, et al. Pressurized liquid extraction with in-cell clean-up followed by gas chromatography-tandem mass spectrometry for the selective determination of parabens and triclosan in indoor dust. J Chromatogr A. 2007;1161 (1-2):105-112. doi:10.1016/j.chroma.2007.05.089

80. Błędzka D, Gromadzińska J, Parabens WW. From environmental studies to human health. Environ Int. 2014;67:27-42. doi:10.1016/j. envint.2014.02.007

81. Purdom C, Hardiman P, Bye V, Eno N, Tyler C, Sumpter J. Estrogenic effects of effluents from sewage treatment works. Chemistry Ecol. 1994;8(4):275-285. doi:10.1080/02757549408038554

82. Grandjean P, White RF, Nielsen A, Cleary D. Methylmercury neurotoxicity in Amazonian children downstream from gold mining. Environ Health Perspect. 1999;107(7):587-591. doi:10.1289/ ehp.99107587

83. Hansen JC, Christensen R, Allermand H, Albøge K, Rasmussen R. Concentrations of mercury, selenium and lead in blood samples from mothers and their newborn babies in four Greenlandic hunting districts: nordisk. The Danish Institute for Clinical Epidemiology. 1984.

84. Clunies-Ross P. Plastics in the environment: te ao hurihuri-the changing world evidence summary. Royal Society Te Aparangi. 2019.

85. Ali N, Mohiuddin S, Mahmood T, Mumtaz M. Monitoring of environmental mercury exposure using hair as bioindicator and the study of potential factors affecting on it in karachi. Am J Analytical Chemistry. 2014;2014.

86. Reporter S Cosmetic products standards finalised. Dawn News Agency; 2019. Availble from: https://www.dawn.com/news/ 1459215. Accessed November 16, 2020.

87. Reporter S PSQCA to launch crackdown against illegal cosmetics. TRIBUNE The Express; 2019. Available from: https://tribune.com. pk/story/1990335/1-psqca-launch-crackdown-illegal-cosmetics. Accessed November 16, 2020.

88. Reporter S Drug, cosmetics act approved. Dawn News Agency; 2020. Available from: https://www.dawn.com/news/1532603/drugcosmetics-act-approved. Accessed November 16, 2020.

89. Commission E Regulation (ec) no 1223/2009 of the european parliament and of the council of 30 november 2009 on cosmetic products (recast). Official Journal of the European Union; 2016. Available from: http://eur-lex.europa.eu/LexUriServ/LexUriServ.do?uri=OJ: L:2009:342:0059:0209:en:PDF. Accessed November 29.

90. Commission E. Approximation of the laws of the member states relating to cosmetic products (7th Amendment Version, 2003). Available from: http://eur-lex.europa.eu/LexUriServ/LexUriServ.do? uri=CELEX:31976L0768:EN:HTML. Accessed Council Directive 76/768/EEC of 27 July 1976 on the. Accessed November 29, 2016.

91. European Commission. SUE reporting guidelines; 2013. Available from: http://ec.europa.eu/growth/sectors/cosmetics/marketsurveil lance/. AccessedDirectorate General for Internal Market, Industry, Entrepreneurship and SMEs. Accessed March 21, 2016.

92. Mukkanna KS, Stone NM, Ingram JR. Para-phenylenediamine allergy: current perspectives on diagnosis and management. J Asthma Allergy. 2017;10.

93. Interest C. The chemistry of henna; 2019. Available from https:// www.compoundchem.com/2019/08/12/henna/.August. 


\section{Publish your work in this journal}

Clinical, Cosmetic and Investigational Dermatology is an international, peer-reviewed, open access, online journal that focuses on the latest clinical and experimental research in all aspects of skin disease and cosmetic interventions. This journal is indexed on CAS
The manuscript management system is completely online and includes a very quick and fair peer-review system, which is all easy to use. Visit http://www.dovepress.com/testimonials.php to read real quotes from published authors.

Submit your manuscript here: https://www.dovepress.com/clinical-cosmetic-and-investigational-dermatology-journal 